\title{
PARO's meeting people with dementia in Copenhagen, Denmark
}

\author{
Lone Gaedt \\ Physiotherapist, Master of Education \\ Project Coordinator, 'Be Safe-project' \\ Demenscenter Pilehuset, Copenhagen, Denmark.
}

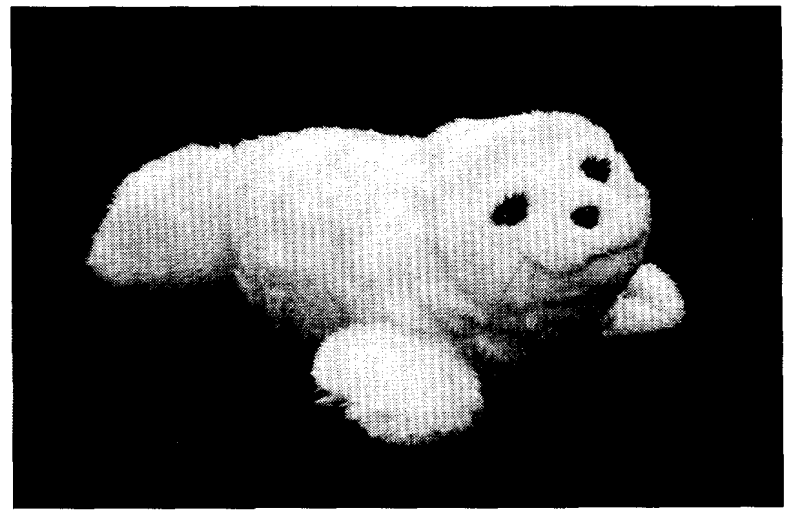

Fig. 1 Seal Robot, Paro

This paper will present and describe

1. The ordinary dementia Care in Copenhagen: organisation, values, challenges

2. Current situation and results in the 'Be Safe-project'. Evaluation.

3. The interest of medias and politicians.

4. Vision for the future for PARO in Denmark.

\section{The ordinary dementia Care in Copenhagen}

In Denmark and in Copenhagen -the capital of Denmark- we have a social care system, financed by the tax system. In Denmark live at about 5 million people, half a million of them living in Copenhagen. Here at about 55.000 people are more than 65 years: 30.000 not receiving Social Care, 20.000 receiving just a little care, and 5000 receiving a care that is more or less intensive, typically in Nursing Homes or Old Peoples Homes. The number of people with dementia in Copenhagen is supposed to be at about 7.000 people, ranging from very mild cognitive impairment to severe impairment, that requests intensive care.

In Copenhagen the politicians have organized the care for the people with dementia after a plan. Each of the 7 districts of the city is going to have its own Dementia Centre with 3 units and services: a daycentre which can be visited in the daytime, one or more days a week, a Rehabilitaion Unit where it is possible to stay 24 hours, for weeks or months, and finally a Dementia Nursing home, where you stay permanently if you need intensive dementia care due to your severe handicap. People in the Dementia Nursing Homes are often difficult to treat and nurse, for example they may be paralyzed, without language, aggressive, depressed, anxious or have other and complex problems.

All the Dementia Care Centres work out from the same values and attitudes: the staff has to take care of the individual person with dementia, and to pay attention to and focus on each persons identity, integrity, dignity, inclusion in the group, meaningful activities, health and quality of life. In order to evaluate the care and caregivers, a special method is used for measuring and developing the quality of the care (the so called 'Dementia Care Mapping', designed by Tom Kitwood, developed at the University of Bradford, England). 
There are several challenges in the future is in relation to the care of the increasing amount of old, handicapped and dement people. Primarily a lot of teaching must be arranged, in order to increase and maintain a high quality of the care. Next to that a problem is, that there is not enough care-givers: in the year of 2020 Denmark probably will miss at about 20.000 care-givers. But the biggest problem may be, that our western countries and communities has a deep and serious sepsis and anxiety to the technological and intelligent systems.

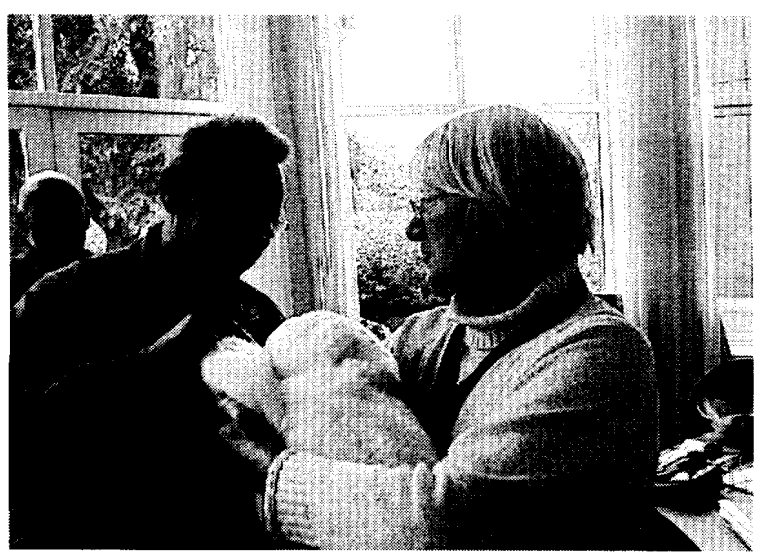

(a)

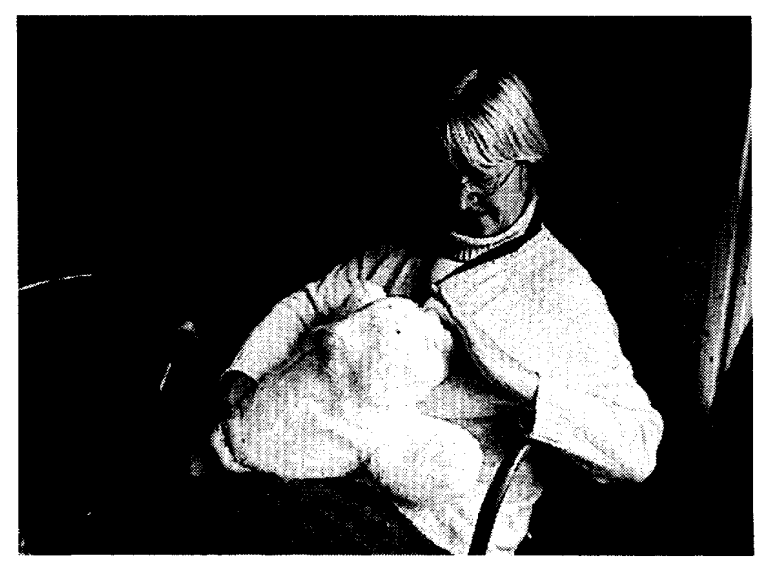

(b)

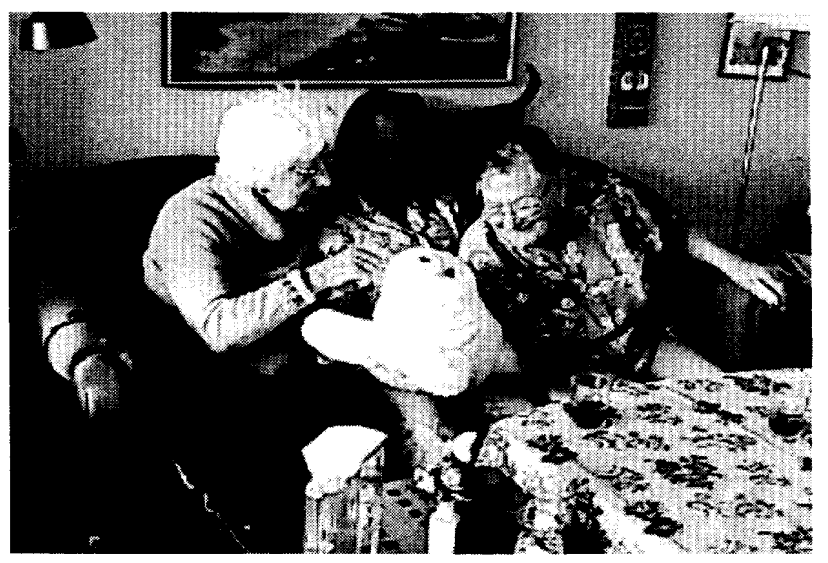

(c)

Fig. 2 Scenes in Dementia Centres

\section{Situation, results and evaluation in the PARO-project}

The 'Be Safe-project' in Copenhagen received 3 mill. DKR from the Ministery of Social affairs in 2006, in order to test the effect of existing and different technological helping aids and systems for people with dementia who were still living at home (people who are not institutionalized). The 'Be Safe-project', that will run until the end of 2007, now is organized in 5 different projects: the Paro-project, a project that minimizes number of people who die in fire and flames, a project that detect people who are disappeared, a project that tests different and minor cognitive technological helping aids, and finally a project that tests out the effect of 'intelligent systems' and smart house technologies. But now we shall focus on the PARO-project.

At 4 of the Dementia Centres in Copenhagen they have during the last time worked with and tried to practice the ideas of Tom Kitwood. These units therefore are supposed to practice and represent a high level of reflection in relation to the dementia care by practising a variety of stimulation and socio-pedagogic methods. The project therefore arranged a pilot-project in autumn 2006, and placed a PARO at one of these units. The result was clear: PARO was a fantastic hit and success to especially one of the women, to the rest of the 12-14 people in the department, PARO didn't mean anything special. Let me show you 3-4 minutes from a DVD. 
The 'Be Safe-project' therefore bought 10 PAROS and on the 23. of May placed them on the 4 Dementia Centres. Until now we have no systematic evaluation, but the tendency is clear: few people respond significantly to PARO, but the people who do respond are VERY fond of PARO: when they get feed-back from PARO they become more awake, they communicate, talk and move more. Others become less anxious and aggressive, and others again are less depressed and apathetic. When the final evaluation has finished, I presume we will be even more satisfied with PARO. The final evaluation will be made out from the Tom Kitwood-method, a video-analysis, different focus-group-interviews and a score measuring the cognitive, behavioral and functional capability of persons with dementia.

3. The interest of medias and politicians.

Different medias have payed a lot of attention to the PARO-project. PARO was in 3 different Television-news (local and national) on the 23. of May, when the 10 PAROs were sent out to the Dementia Centres. Since then PARO has 'performed' in other TV-and radio programs and different newspapers, also because there is an ongoing attention to the jubilee of the Danish Ethical Committee, and therefore attention to the human aspects of technology.

The next time we will meet the interest of the medias, will be when the final evaluation is produced. I am sure the evaluation will produce a lot of attention.

I will like to show you 5 minutes from the national TV-News, also in order to present, picture and describe the Danish (and European) attitude to and fear for modern technology: in our countries and communities, the is a fear for technology restating persons and personal relations.

4. Vision for the future for PARO in Denmark.

By the end of the project, we will be able to describe how PARO works for the individuals, and also interpersonally in the Dementia Centres in Copenhagen. Thereby the project will be able to answer some of the hot political and ethical questions: does the technology help and support the person with dementia? Can technology replace personal care?

（日本語訳：産業技術総合研究所・柴田崇徳）

$$
\begin{gathered}
\text { ローン・ガェット } \\
\text { 理学療法士、教育学修士 } \\
\text { Be-Safe プロジェクト・コーディネーター } \\
\text { 認知症センター、コペンハーダン、デンマーク }
\end{gathered}
$$

この論文は、次の 4 つの項目を述べる。

1.コペンハーゲンにおける通常の認知症ケア : 組織、価值、挑戦

2.「Be Safe」プロジェクトの現状と結果 : 評価

3.メディアと政治家の興味

4. デンマークにおけるパロの将来展望

1.コペンハーゲンにおける通常の認知症ケア

デンマーク王国（以下、デンマーク）や首都コペンハーゲンでは、税金による社会ケアシステムがある。 デンマークの人口は約 500 万人で、そのうち約 50 万人がコペンハーゲンに住んでいる。さらにそのうち 65 歳以上は 5 万 5 千人である。3 万人は社会ケアを受けておらず、2 万人は若干の社会ケアを受け、5千

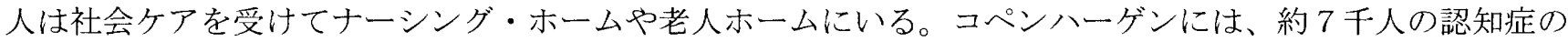
人々がいる。非常にマイルドなレベルから多くのケアが必要な重度の認知症まで様々である。

コペンハーゲンでは、政治家が認知症の人々のケア政策を打ち出した。コペンハーゲンの7つの区域のそ れぞれに 3つのユニットとサービスからなる「認知症センター」を設置しようとしている。 3 つのユニット とサービスは、まず認知症の人が日中訪問する「デイ・サービス」、数週間から数ヶ月滞在することが可能 な「リハビリテーション・ユニット」、そして重度の障害により多大な認知症ケアが必要な人が生涯を過ご す「認知症ナーシング・ホーム」から構成される。「認知症ナーシング・ホーム」にいる人々は、通常、介 護や扱いが難しい場合が多い。例えば、彼らは麻痺したり、言葉を失ったり、攻撃的になったり、「うつ」 になったり、不安になったり、そのほか様々な問題を起こしたりするからである。

すべての「認知症センター」は、同一の価值や態度で機能している。スタッフは、個々の認知症の人の世 話をし、それぞれの個性、規範、尊峳、グループへの㷌属、意味ある行動、健康、生活の質に対して、注意 
を払い、集中しなければならない。ケアと介護者の評価を行うために、特別な方法がケアの質の計測と発展 に用いられている。それは、英国ブラッドフォード大学でトム・キットウッド教授によりデザインされた 「認知症ケア・マッピング」と呼价る方法である。

増加している高齢者、障害者、認知症の人々のケアに関連して、いくつかのチャレンジが行われている。 ケアの高度な価值を増加・維持するために、主には多くの「教育」が準備されなければならない。次には、 介護者の不足が問題である。デンマークでは、2020 年には 2 万人の介護者の不足が予想される。しかし、 一番大きな問題は、西洋の国々やコミュニティでは、テクノロジーやインテリジェント・システムに対して 樑く深刻に否定したり、不安を感じたりすることである。

\section{2.「Be Safe」プロジェクトの現状と結果}

コペンハーゲンの「BeSafe」プロジェクトは、2006 年に社会省から３００万クローナ（約６５００万 円）を受託した。施設に生活する人々ではなく、まだ家庭で生活している認知症の人々のための、既存の 様々なテクノロジーの支援方法やシステムの効果をテストすることを目的にしている。「Be Safe」プロジェ クトは、2007年末まで行われ、その中に 5 つのプロジェクトがある。「パロ・プロジェクト」、「火事 で亡くなる人の減少・プロジェクト」、「不明になる人を探し出すプロジェクト」、「認知的技術的な支援 手法のテスト・プロジェクト」、「インテリジェント・システムとスマート・ホーム技術の効果のテスト・ プロジェクト」である。ここでは、「パロ・プロジェクト」に集中寸る。

コペンハーダンの 4 つの認知症センターにおいて、トム・キッドウッドの考えを実践してきた。そのため、 これらの 4 つの認知症センターでは、様々な刺激や社会教育学方法の実践による認知症ケアに関して、高い レベルの効果を示している。そこで、2006 年秋にパイロット・プロジェクトとして、まず1つの認知症 センターに 1 体のパロを導入した。結果は、明らかであった。パロは、ファンタスティックなヒットで、 1 3 名から 15 名の人々に対して、特に一人の女性には大成功であった。パロが特殊なもの、というわけでは ない。ここで $3 、 4$ 分のビデオを見せる。

そのため「BeSafe」プロジェクトは、さらに 10 体のパロを購入し、5月 23 日から 4 つの認知症センタ 一にパロを導入した。これまでに、システマティックな評価は無いものの、傾向は明らかである。パロに対 して極端に反忘する人はほとんどいないが、パロに反忘を示す人は、パロのことを非常に好きである。パロ からフィードバックを受けた人は、より意識がはっきりし、一層、会話をしたり、話をしたり、動いたりす るようになる。また、不安や攻撃性を減少させたり、「うつ」や無関心さを改善したりする。最終の評価を 実施する頃には、我々はパロに対してより一層の満足感を得ると考えている。最終評価は、トム・キッドウ ッド方式、ビデオ解析、異なるグループヘのインタビュー、認知症の人の認知・行動・機能能力のスコア測 定によって行う予定である。

\section{3.メディアと政治家の興味}

様々なメディアがパロ・プロジェクトに非常に注目している。10体のパロが認知症センターに送られた 2007 年 5 月 23 日には、3つのテレビ・ニュースで紹介された。それ以来、パロは他のテレビ、ラジオ、 新聞で登場している。また、デンマーク倫理委員会の注目していることから、テクノロジーにおける人間の 側面への関心も高い。メディアの次の関心は、最終評価が実施される時である。その結果は、一層の関心を 集めるに違いない。ここで、デンマークの全国ニュースを 5 分間紹介する。これは、デンマークやヨーロッ パの人々の現代のテクノロジーに対する態度や不安を表現している。

\section{4. デンマークにおけるパロの将来展望}

プロジェクトの終了までには、パロが個々人や、認知症センターの人々の間にどのように働きかけるかを 明らかに出来るであろう。そして、このプロジェクトが「テクノロジーが認知症の人を助け、支援するの か?」、「テクノロジーが人によるケアを置き換えられるのか?」という政策と倫理のホットな問題に対し て答えるであろう。 